\title{
Managing Political Behavior of University Students
}

\author{
Junaidi Awang Besar ${ }^{1}$ \\ Mohd Fuad Mat Jali2 \\ Novel Lyndon ${ }^{3}$
}

Sivapalan Selvadurai ${ }^{4}$

\begin{abstract}
1 Lectures at School of Social Development and Environmental Studies, Faculty of Social Sciences and Humanities, University Kebangsaan Malaysia, Bangi, UKM 43600, Selangor D. E., Malaysia, jab@ukm.edu.my ${ }^{2}$ Professor at School of Social Development and Environmental Studies, Faculty of Social Sciences and Humanities, University Kebangsaan Malaysia, Bangi, UKM 43600, Selangor D. E., Malaysia, fuad@ukm.edu.my ${ }^{3}$ Associate Professor at School of Social Development and Environmental Studies, Faculty of Social Sciences and Humanities, University Kebangsaan Malaysia, Bangi, UKM 43600, Selangor D. E., Malaysia, novel@ukm.edu.my ${ }^{4}$ Associate Professor at School of Social Development and Environmental Studies, Faculty of Social Sciences and Humanities, University Kebangsaan Malaysia, Bangi, UKM 43600, Selangor D. E., Malaysia, sivap02@gmail.com
\end{abstract}

\section{Doi:10.5901/mjss.2015.v6n4s3p48}

Abstract

The main objective of the institute of higher learning is to produce students who are excellence in academic, innovative and prepared to face any challenges. Besides learning various disciplines of knowledge they also participate in campus politics. This article analyses the factors which form student political behavior on the campus and strategy undertaken by management and lecturer to make students innovative and progressive. A survey using questionnaires was carried out from a sample of 800 students in the main campus of the Universiti Kebangsaan Malaysia (UKM). The result of the study shows that student political behavior was influenced by their family background and campus environment. The other factors are location and campus environment, welfare, racial composition, state of origin, mass media, issues, lecturer and university leadership. The strategy undertaken by the UKM management are to give more attention on student welfare, monitoring students activities, practicing student friendly policy and concept of hands on, introducing patriotic courses, built-up close relationship between student and top leadership and student union. Thus managing political behavior of campus students would be very interesting and challenging indeed for future analyses to look again into the question of young voting pattern in Malaysia.

Keywords: political management, students, globalization, leadership, association

\section{Introduction}

Students in higher education is a group of elite and educated youth. In addition to studying various disciplines, they are also active in campus political activities. Their political behavior patterns could threaten the campus and national politics. Their political participation will influence the campus and national political scenario when involving community issues, policy and leadership. University is one of important social institution and looked up to by society because this institution produces a large portion of elite group or educated person. Student political activism remains a key issue in the Third World despite its decline in industrialized nation. Students those in the social sciences, are fairly easy to mobilize and they often have a basic interest in political and social issues (Altbach, 1984). It is argued that student movements emerge from their social and political environment and it is not surprising that activism continues as a powerful for in the Third World. To examine this point this article analyses what are the factors that caused student interested in politics and strategy to manage this problem.

\section{Literature Review}

In Indonesia for instance student's movement as the largest pressure group had played a role bringing down President Suharto's government. The students' movement in Thailand, Filipina, Cuba, Southern Korea, Europe and America too 
have an impact on the social well-being and security (Mohd Fuad et al., 2009). However the important in this matter is their radical actions and behavior that show anti establishment. This confrontation between government side and student however never subside from time to time. This situation continues until today where students' has been placed under the University and University College Act (AUKU).

Malaysia also had experienced campus political phenomenon and it started in 1960'sand early 1970's, with the occurrence of students' demonstrations. It was at the end of 1990's, a worst riot broke out which threatened national security. Some of student involved together with lecturer or individually in political campaign, became members of opposition party, fight against government policy and joined in street demonstration (Mohd Fuad et al., 2005; Muhammad, 1973). Thus political issue became a topic of discussion among student in campus and their activity always get the attention of the university administration and the government. Students' political participation became an important issue because it raises certain implications on present political influence, from government perspective or opposition party (Mustaffa, 1991). Some of the event and political scene in young generation is includes certain challenges that they need to face, some of that are rhetorically as opportunity for them to build interest and competency politicking which contains a particular vision and political mission (Razaq, 2005). Student movement has expanded and has get the support of the opposition parties (Hussain, 1997). This situation affected the government position and university management (Azizan, 1995). Consequently the Malaysian government introduced a University and University College Act in 1971 to take control student movement in campus and country and it is well received by student (Altbach, 1968). However this act has change undergraduate political behavior and activity in the campus only and less sensitive on social issues and political (Azizan, 1995).

Young generation has influenced by materialistic elements and poor in appreciation to good values. This is an attack on our society's socio cultural destruction not just happen in community in fact it also spread among student that regarded as a future leadership, religion, and country (Muhammad, 1973). Students are active in co-curriculum and they concern about campus life and society problems but voting turnout for campuses election is less from 50 percent, except in several universities which has made rule that their marks will be deducted if they are not voting. In Australia, participation in school elections serves as a beneficial experience in the preparation of students for life as an active adult citizen (Mohd Fuad et al., 2005; Ramírez, L.G. et al., 2010; Ruitenberg, 2010). Students in power roles reported a greater understanding of and appreciation for the legislative process and found the simulation to be a more worthwhile experience than did students in non-power roles (Saha \& Print, 2010). Student activism has made an important contribution to the struggle for democracy in Zimbabwe. In the first years of independence students were among the most fearsome defenders of the regime (Baranowski \& Weir, 2010). All facets of personality captured by the Big Five framework matter for citizen politics, and that personality effects operate on virtually all aspects of political behavior (Zeilig, 2008). Awareness of and identification with non-news television formats which suggests that sources such as TV talk and reality shows may be important sources of political discourse and even civic engagement among the students (Mondak \& Halperin, 2008). For future research in both areas should deal more centrally and explicitly with these inherently political dimensions of sustainability (Smith \& Stirling, 2010).

The U.S. medical students are considerably more likely to be liberal than conservative and are more likely to be liberal than are other young U.S. adults (Frank et al., 2007). Future U.S. physicians may be more receptive to liberal messages than conservative ones, and their political orientation may profoundly affect their health system attitudes (Dunsmore \& Lagos, 2008). Some of the political and resource issues are importance in proposing and obtaining support for a mandatory student clerkship (Alam, 2003). In Bangladesh, students' politics has a serious impact on the institutional management, education system, national development and state business (Frank et al., 2007; Alam et al., 2011). In South Korea, it is found that students who are radically socialized via left wing organizations and issues are more likely to show higher level of approval of communism and more support for protest activity (Aie, 1997).

Social background factors play a minor role in determining the amount of political activism a student would engage in. Student activism is being criticized by the public and by the students themselves because of the underlying revolutionary ideologies and several episodes of violence (Aie, 1997; Zaman et al., 2010). Besides that, the student not only able to change campus political behavior but also affords overthrowing government (Azizan, 1995 \& Altbach, 1968). Citizenship education in established democracies is challenged by declining youth participation in democracy. Youth disenchantment and disengagement in democracy is primarily evident in formal political behaviour, especially through voting, declining membership of political parties, assisting at elections, contacting politicians, and the like (Print, 2007). An open classroom climate has a positive impact on adolescents' civic knowledge and appreciation of political conflict, even upon controlling for numerous individual, classroom, school, and district characteristics (Campbell, 2008). Private religious schools have the most active councils engaged in a wide range of activities, but their decisions and memberships are constrained by a great deal of faculty oversight. Such variation in representative government has 
implications for political socialization and the types of citizens (Mcfarland \& Starmanns, 2009). Citizenship education can influence young people's participation above and beyond these other factors and whether this is more likely if a school adopts a particular approach to the subject's delivery (Lopes et al., 2009).

Voluntary organizations are powerful political socialization agents leading to young people engaging in politics. Young people who are members of several organizations are more active in politics, while spending a greater amount of time in one organization does not increase level of political participation (Quintelier, 2010). Through a multilevel analysis, the simultaneous effect of formal civic education, active learning strategies and school characteristics on political participation among Flemish student is investigated and the evidence suggests that especially formal education and active learning strategies are successful in stimulating political participation (Quintelier, 2010). Student movements in 1998 and after in Indonesia have relied on a specific masculine style that draws on both the authenticity of nationalist historical narratives and the street as the domain of the people, and in the process masks potentially contentious class and gender differences among progressive activists (Lee, 2011a; Lee, 2011b). For integrating politics into the design of reflexive governance, that was two way: to solve it: (1) recognize the politics of learning for sustainable development and develop safeguards against domination and capture by powerful actors, and (2) systematically consider the embedding of governance designs in political contexts and their ongoing dynamics for political fit (Jan-Peter Voß 1 \& Bornemann, 2011). The youths regarded the BN's slogan "One Malaysia: Priority to the People and Achievement" as worthy of their support. So were the policies and leadership of the Prime Minister and his deputy, in particular, the newly instituted Key Performance Indicators of the members of parliament and of the state and federal ministers (Junaidi et al., 2010; Junaidi et al., 2011; Mohd Fuad et al., 2011; Mohd Fuad \& Junaidi, 2012a; Mohd Fuad \& Junaidi, 2012b). Palestinian adolescents reported more trust in the political system, were more aware and had a more formulated opinion of the political system than their Jewish colleagues. In addition, it was found that more religious adolescents showed more political awareness and involvement (Attar-Schwartz \& Ben-Arieh, 2012). Affirmative action policies came into effect in Sri Lanka in the 1970s with the left-of-centre United Front government headed by Sirimavo Bandaranaike. Her government introduced changes in the criteria for university admission, initially designed to benefit the majority Sinhalese students. These policies were later transformed into a regional quota system cutting across ethnic and religious identities. The schemes were condemned for straying away from principles of merit and fairness, failing to guarantee social mobility through education and limiting the number of Tamil students in the science and medical faculties (Wickramasinghe, 2012).

\section{Methodology}

\subsection{Area of study}

Universiti Kebangsaan Malaysia (UKM) is situated in the state of Selangor in the Central Region of the Peninsula Malaysia. It has a population of 4.5 million (comprising 51.9 per cent Malay, 29.2 per cent Chinese and 14.9 per cent Indian and others) and has 1.4 million registered voters (2004). The state has one of the largest collections of industries and most of them are situated in the Klang Valley industrial zones. Consequently it becomes one of the wealthiest and most developed state and nation's vital administrative and business centre's. UKM is a public university located in Bangi, Selangor which is about $35 \mathrm{~km}$ south of Kuala Lumpur. Its teaching hospital is located in Cheras and also has a branch campus in Kuala Lumpur. Currently there are 17,500 undergraduate students enrolled, and 5,105 postgraduate students of which 1,368 are foreign students from 35 different countries.

\subsection{Data collection and analysis}

A sample of 800 UKM students was selected for survey. The sample was stratified according to faculty and year of study. Respondents were chosen by a random procedure in which interviewers visited the colleges or at the faculty. The questionnaire was conducted in Malay and English language. It was structured to discover the political behavior of student in UKM. All the data that have been collected from the survey were coded and analyzed descriptively using SPSS to get the frequency and percentage of the responds. 


\section{Results and Discussion}

\subsection{UKM student politics orientation}

Student are known as intellectual group that have vision, alert, sensitive to society and has been categories as group that have high political consciousness (Junaidi, 1993). Their awareness has created various political dimension and help to shape the pattern of political behavior. There are six categories of activities that had been carried out to nurture their politics. The result of the study shows that the large is organization activist, 24.6 per cent of the students are grouped in this category. They normally put a lot of time, effort or energy for the organization or politics campus and they also became pressure group or lobbying. The second is Contributor, 19.7 per cent involved voluntarily in campaign tease. They will follow their leaders from faculty to faculty helping to explained organization ideology and manifesto to students in campus. They do it before a lecture starts or during the interval. Opinion giver is the third category, 19.8 per cent of them always talked politics with their family when they back home and among friends in the campus or colleges. Fourth is voter, students voted in campus election or national election but do not commit more than that. Fifth is Non-voter, students that seldom or have never voted but have minimum interest in campus politics. Lastly apolitical, 22.8 percent of the students who have very little knowledge about politics or not interested at all.

From the students' point of view, their involvement in politics is regarded as a modernization process or maturity. Their political awareness is high on social issues such as poverty, education, health, scholarship and student welfare. The development of technology, communication and development of knowledge have expedited the changing dimension of undergraduate politics behavior (Hussain, 1997). They are very active in stimulating change, motivated and had awareness of civil rights. It is found out that 30.7 per cent of the UKM's students used internet as a source of political information's and supported party that fight the right of the civil society. The rises of Islamic movement is also motivates student in campus politics. The activity almost similar with the actual situation outside the campus i.e. associated with a political party. Thus their awareness and political behavior among the undergraduate students in UKM are predictable and it is more to the left. Its mean that the higher the political consciousness level of the students, the tendency to choose the opposition party is greater. UKM has a population of 14,100 undergraduate students (2009) from various races and backgrounds. They have different dimensions, political ideologies and cultures. Since 1996 to 2002, campus political helmed by opposition party that cultivate anti-establishment and university management. This unhealthy situation has been analyzed and the factors are as follows:

\subsubsection{Identification party inherited from the origin state}

Theory of identification party stated that a person political party is inheriting from parents and environment. However their party identification will change due to socialization and learning process. When they register as student at the university, they normally have identified what party they like most. The survey shows that such pattern exist among student from UKM. From 800 respondents it was found that 29 per cent is those who hail from eastern region (the state of Pahang, Terengganu and Kelantan), followed by the state of Selangor, Johor and Kedah which is both 10 per cent and 9 per cent respectively. This situation was correlated with political party choice, it was found out that 24.3 per cent choose the opposition party (PAS) and 37.1 percent wanted to maintain student's top leadership of the Angkatan Perpaduan Ummah (APU). It is proved that the factor is inherited from family political ideology when 24.5 per cent that their parents also became a member of the opposition party. In conclusion student's family party identification and country of origin influence current political performance pattern formation in campus.

\subsubsection{Location and campus environment}

Location and environment where the institution located also influence character and campus life culture. UKM situated in the Klang valley region, that fast developing or in elite industrial area and had high accessibility. UKM nearby Kuala Lumpur and closed with other universities such as Universiti Putra Malaysia (UPM), Universiti Malaya (UM), Universiti Islam Antarabangsa (UIA). It easy to exchange idea, influence, competition and shaped academic activity, social, political and religious. Neighborhoods factor and environment play direct role in shaping political ideology in campus. For instance the situation occurred in 1998 namely street demonstration movements by reformers have influenced UKM's students. Campus has become external political arena that tarnishes student political values.

Student who are active in campus also active with outside politics activity. The finding was found that 34.4 per cent of student UKM attends politics talk outside the campus and 21.3 per cent have helped in campaign for opponents' party. 
Their frequencies attend opponent party politics talk is twice in one month (34.1 per cent say 'yes'). Those who present to hear political talk in campus only 25.5 per cent and only 7.5 per cent only that have attended to association meeting campus political. This is showed that campus political situation in 90's year ending year and early 2000 in domination by outside party. The percentage of support Islam Penyelamat Ummah (IPU) reaches to 73.6 per cent and 57.9 per cent in year student representative's council election 2001 and 2002. Only 26.4 per cent and 42.1 per cent for Pro-establishment has support by the students.

\subsection{University leadership's hopes}

AUKU has gave impact to student political activies. According to Kee Kok Joo, Vice President of Majlis Perwakilan Pelajar Universiti Malaya (MPMUM), there are several provisions that need to be loosened because limit and not expand student intellectuality like freedom of voice opinion, gathered and move. According to him, the Hal Ehwal Pelajar (HEP) must has an attitude that more open to Majlis Perwakilan Pelajar (MPP) and to keep students social welfare. This point of view also is shared by UKM's student where 56.1 per cent wanted AUKU amended with present situation and globalization current that they face. The 45.1 percent also wanted top leadership and HEP more honest. Give a lot of opportunities to speak (53.1 per cent) and wanted university more concerned on student welfare. UKM's student wanted university's top leadership invite student leaders in policy making related to them. They also able to influence decision university's top leadership. At that time this situation will make anxiety among student and will definitely give an effect to university management and government. For opposition, situation like this what they are awaited for and made an issue to poison mind and undergraduate politics behavior.

\subsection{Management of political campus politics}

Leadership of every university mutually replace and they are responsible to ensure academic excellence and behavior of the student in keeping with status quo. UKM political pattern in a decade ago side with anti-establishment party. Only in year 2003, student representative council had won by Aspirasi that more pro to state by getting 23 from 32 seats that contested and obtain 71.6 a percentage of total votes. In year 2001 and 2002, Aspirasi only managed to win respectively 1 and 9 from 32 seats that have contested. In that year also, voting process and candidate selection was changed. The changes made are candidates that qualified to compete is consisting of year two and above and candidate posters centralized in certain places that run by student affairs. Balloting process on the other hand held at PUSANIKA (for those stay outside of the campus) and all over residential college, and there's no longer held at faculty and morning lecture also cancelled. This strategy had a positive effect to percentage of students who are attend to poll section which is 81.30 per cent. This per cent is a superlative within 13 election years which held in UKM (the highest percent was 85.95 per cent in year 1985/86). The winning by the Aspirasi at year 2003 carry one campus political reform in conjunction with new top leadership transition in UKM. As a result of research that carried out existing a few factors which contribute to that success.

The concerns' of management on student welfare more emphasized and made a prime agenda. This is suitable with student hope who wants university more give convergence on welfare affairs and social. For instance in financial issue which is loan or scholarship need to accordance with schedule and hostel fees. Although the price increase around 50 cents to RM1 but it is because of to upgrade the furniture, bathroom and other facility. This is mean student able to have a good accommodation that more comfortable and reasonable. The other strategy is to get hands on has been committed by management. For instance in year 2002 year and early 2003 various activities that enacted especially for student with universities top leadership. Vice Chancellor together Deputy of Vice Chancellor and university's senior officers held dialogue session with students in residence colleges. This activity will make a closer relationship between management and students. There is 80 per cent from student state this effort is very good because they able to share all problem. The other activities that organize by HEP also help to nurture the culture and identity as a UKM student. Almost 50 activities held in a year and it focuses on leadership, community services, academic, management, organization, religion, career and also others activities. For Faculty of Social Sciences and Humanities, one of the programs was held from 1994 until today is Program Kecemerlangan Pelajar. In this program, the students are involved with motivation, self management in term of academic and humanities and also interview practices.

\section{Conclusion}

Family factor is the most influence political behavior of students gives an impact in campus life. The students has been 
shaped or inherited from their family and will changed when it come a few process of learning in campus. Universiti Kebangsaan Malaysia is able to control the students' political behavior from anti-establishment to pro-establishment thru a few strategies. Vice Chancellor, Deputy Vice Chancellor and other officers are successful to manage students' needs and to solve the students' problems. In conclusion, this study has an impact on student programmed, student affairs and university's managers to compromise the needs and aspirations of the student.

\section{References}

Aie, R. L. (1997). Exploration of the sources of student activism: The case of South Korea. International Journal of Public Opinion Research, 9(1), 48-65. http://ijpor.oxfordjournals.org/content/9/1/48.full.pdf

Alam, G.H., Rabby, T.G., Boon, T.I., Khan, I. And Hoque, K.E. (2011). National development and student politics in Bangladesh. African Journal of Business Management, 5(15), 6044-6057. http://www.academicjournals.org/ajbm/PDF/pdf2011/4Aug/Alam\%20et\% 20al.pdf

Alam, G.M. (2003). The impact of students' involvement in party politics on higher education in national development in Bangladesh. Missouri: The International University Press.

Altbach, P.G. (1968). Students politics in Bombay. London: Asia Publishing House.

Altbach, P.G. (1984). Student politics in the Third World. Higher Education, 13(6), 35-55.

Attar-Schwartz, S., Ben-Arieh, A. (2012). Political knowledge, attitudes and values among Palestinian and Jewish youth in Israel: The role of nationality, gender and religiosity. Children and Youth Services Review, 34(4), 704-712. http://dx.doi.org.www. ezplib.ukm.my/10.1016/j.childyouth.2011.12.017

Azizan, B. (1995). Belia dan Masyarakat. [Youth and Community]. Kuala Lumpur: Institut Kajian Dasar.

Baranowski, M., Weir, K. (2010). Power and politics in the classroom: The effect of student roles in simulations. Journal of Political Science Education, 6(3), 217-226. http://www.tandfonline.com/doi/abs/10.1080/15512169.2010.494465

Campbell, D.E. (2008). Voice in the classroom: How an open classroom climate fosters political engagement among adolescents. Political Behavior, 30(4), 437-454. http://www.springerlink.com.www.ezplib.ukm.my/content/tg004q3118570213/DOl:10.1007/s 11109-008-9063-z

Dunsmore, K., Lagos, T.G. (2008). Politics, media and youth: Understanding political socialization via video production in secondary schools. Learning, Media and Technology, 33(1), 1-10. http://www.tandfonline.com/doi/abs/10.1080/17439880701868770

Frank, E., Carrera, J., Dharamsi, S. (2007). Political self-characterization of U.S. medical students. Journal of General Internal Medicine, 22(4), 514-517. http://www.ncbi.nlm.nih.gov/pmc/articles/PMC1829428/

Hussain, M. (1997). Belia di Malaysia: Masalah, gerakan dan masa depan. [Youth in Malaysia: Problems, Movements and Future]. Kuala Lumpur: Aneka Publishing.

Junaidi, A.B. (1993). Mahasiswa, politik dan undang-undang. [Students, Politics and Law]. Kuala Lumpur: Dewan Bahasa dan Pustaka.

Jan-Peter Voß \& Bornemann, B. (2011). The politics of reflexive governance: challenges for designing adaptive management and transition management. Ecology and Society, 16(2), 9. http://www.ecologyandsociety.org/vol16/iss2/art9/

Junaidi, A.B., Mohd Fuad, M.J., Abdul Halim S., Yahaya I., Noor Aziah M.A. \& Khaidzir I. (2010). Analisis trend pengundian berdasarkan kaum di kawasan Bukit Gantang, Perak. [Analysis of voting trend according to ethnic in Bukit Gantang, Perak]. E-Bangi, Journal of Social Sciences and Humanities, 5(1), 26-37. http://pkukmweb.ukm.my/e-bangi/papers/2010/junaidi010.pdf

Junaidi, A.B., Mohd Fuad, M.J., \& Mohd Faidz, M.Z. (2011). Kajian budaya politik Melayu dalam pilihan raya kecil Hulu Selangor, Selangor. [Malay political culture studies on by election in Hulu Selangor, Selangor]. Jurnal Melayu, 8, 153-172. http://journal article.ukm.my/3480/1/bil\%25208\%2520-\%2520topik\%25208.pdf

Lee, D. (2011). Styling the revolution: Masculinities, youth, and street politics in Jakarta, Indonesia. Journal of Urban History, 37(6), 933951. doi:10.1177/0096144211410526 SAGE Publications. http://juh.sagepub.com/content/37/6/933

Lee, D. (2011). Images of youth: On the iconography of history and protest in Indonesia. History and Anthropology, 22(3), 307-336. http://www.tandfonline.com.www.ezplib.ukm.my/doi/pdf/10.1080/02757206.2011.595003

Lopes, J., Benton, T., Cleaver, E. (2009). Young people's intended civic and political participation: Does education matter?. Journal of Youth Studies, 12(1), 1-20. http://www.tandfonline.com/doi/abs/10.1080/13676260802191920

Mcfarland, D.A., Starmanns, C. (2009). Inside student government: The variable quality of high school student councils. Teachers College Record, 111(1), 27-54. http://www.tcrecord.org/Content.asp?ContentID=15173

Mohd Fuad, M.J., Rashila, R., Mohd Yusof, K. (2005). Minat, aspirasi dan pilihan politik belia IPT Malaysia. [Interests, aspirations and Higher Education Institutions of Youth Political Choice]. Prosiding Seminar Penyelidikan Pembangunan Generasi Muda: Realiti Generasi Muda Melangkah Ke Hadapan. Universiti Kebangsaan Malaysia: Fakulti Sains Sosial dan Kemanusiaan: 113-120.

Mohd Fuad, M.J., Junaidi, A.B., Abdul Halim S., Noor Aziah M.A. (2011). Persepsi politik belia di kawasan Dewan Undangan Negeri (DUN) Bagan Pinang, Negeri Sembilan. [The political perception of the youths in the state assembly area of Bagan Pinang, Negeri Sembilan]. Malaysian Journal of Society and Space (Special Issue: Social and Spatial Challenges of Malaysian Development), 7, 105 - 115. http://www.ukm.my/geografia/images/upload/9.geografia-2011-4-sp-BAGAN\%20PINANG\%20-fuad $\% 20 \% 20 j a l i \% 20 \mathrm{kkm}-1 \mathrm{am}$. doc.pdf

Mohd Fuad, M.J., Yahaya, I., Noor Aziah, M. A., Abdul Halim, S. \& Khaidzir, I. (2009). Minat, aspirasi dan sokongan politik belia IPT Malaysia. [Interests, aspirations and Higher Education Institutions of Youth Political Support in Malaysia]. Malaysian Journal of 
Youth Studies, 1(6), 99-116. http://www.ippbm.gov.my/v2/index.php?option=com_content\&view=article\&id=521\&ltemid=46\&lang $=b m$

Mohd Fuad, M.J., \& Junaidi, A.B. (2012a). Pembangunan sosioekonomi dan pandangan belia terhadap isu semasa di kawasan Parlimen Batu, Wilayah Persekutuan Kuala Lumpur. [Socio-economic issues in the Batu parliamentary area of Kuala Lumpur: Perception of local youths]. Malaysian Journal of Society and Space (Special Issue: Social and Spatial Challenges of Malaysian Development), 8(2), 67-76. http://journalarticle.ukm.my/3611/1/7.geografia-peb\%25202012-themed\%2520issue-fuad\%2520dkkukm-melayu\%2520-22.2.pdf

Mohd Fuad, M.J., \& Junaidi, A.B. (2012b). Pendapat dan keperluan generasi muda di kawasan parlimen Muar, Johor. [Opinion and the needs of young generation in Muar parliamentary constituency, Johor]. E-Bangi, Journal of Social Sciences and Humanities, 7(1), 50-63. http://journalarticle.ukm.my/2827/1/fuad012.pdf

Mondak, J.J., Halperin, K.D. (2008). A framework for the study of personality and political behaviour. British Journal of Political Science, 38(2), 335-362. http://journals.cambridge.org/action/display;jsessionid=C697FA713646FC076974EF098A052C30.journals ?fromPage $=$ online \&aid $=1701816$

Muhammad, A.B. (1973). Mahasiswa Menggugat. [Students sue]. Kuala Lumpur: Penerbit Pustaka Antara.

Mustaffa, A. K. (1991). Gerakan Pelajar dan Mahasiswa: Misi dan Visi. [Students and Student Movement: Mission and Vision]. Petaling Jaya: Budaya Ilmu Sdn Bhd.

Print, M. (2007). Citizenship education and youth participation in democracy. British Journal of Educational Studies, 55(3), 325-345. http://onlinelibrary.wiley.com/doi/10.1111/j.1467-8527.2007.00382.x/pdf

Quintelier, E. (2008). Who is politically active: The athlete, the scout member or the environmental activist?: Young people, voluntary engagement and political participation. Acta Sociologica 51, (4), 355-370. doi: 10.1177/0001699308097378 http://asj.sagepub. com/content/51/4/355

Quintelier, E. (2010). The effect of schools on political participation: A multilevel logistic analysis. Research Papers in Education, 25(2), 137-154. http://www.tandfonline.com/doi/pdf/10.1080/02671520802524810

Ramírez, L.G., Martínez, J.C., Sánchez, F.A. (2010). Politics and youth in university life: A case study [Política y juventud en la vida universitaria: Un estudio de caso]. Utopia y Praxis Latinoamericana, 15(50), 71-90. http://www.scielo.org.ve/pdf/upl/v15n50 lart06.pdf

Razaq, A. R. (2005). Mahasiswa Abad 21. [Student Ages 21]. Bangi: Universiti Kebangsaan Malaysia.

Ruitenberg, C.W. (2010). Queer politics in schools: A Rancièrean reading. Educational Philosophy and Theory, 42(5-6), 618-634. http://onlinelibrary.wiley.com/doi/10.1111/j.1469-5812.2010.00689.x/abstract

Saha, L.J., Print, M. (2010). Student school elections and political engagement: A cradle of democracy?. International Journal of Educational Research, 49(1), 22-32. http://www.sciencedirect.com/science/article/pii/S0883035510000406

Smith, A. \& Stirling, A. (2010). The politics of social-ecological resilience and sustainable socio-technical transitions. Ecology and Society, 15(1), 11. http://www.ecologyandsociety.org/vol15/iss1/art11/

Wickramasinghe, N. (2012). Democracy and entitlements in Sri Lanka: The 1970s crisis over university admission. South Asian History and Culture, 3(1), 81-96.

Zaman, Q., Atif, M., Shah, H., Ayub, G., Farooq, M. (2010). Key Factors which Cause the Anxiety among the University Students: A Case Study Based on an Event Happened in Peshawar Campus. European Journal of Social Sciences, 16(1), 87-96. http://www.eurojournals.com/ejss_16_1_09.pdf

Zeilig, L. (2008). Student politics and activism in Zimbabwe: The frustrated transition. Journal of Asian and African Studies, 43(2), 215237. http://es.s.sagepub.com/content/6/1/69.full.pdf+html 